УДК 633.854.78:631.559

(C) 2017

Гарбар Л. А., кандидат сільськогосподарських наук,

Горбатюк Е. М., здобувач

Національний університет біоресурсів і природокористування України

\title{
ОСОБЛИВОСТІ ФОРМУВАННЯ ПРОДУКТИВНОСТІ ПОСІВІВ СОНЯШНИКУ
}

\section{Рецензент - кандидат сільськогосподарських наук Н. П. Бордюжа}

Наведено результати досліджень, спрямованих на вивчення впливу строків сівби та ширини міжрядь на формування продуктивності посівів різних гібридів соняшнику. Дослідження проводились протягом 2014-2016 рр. в умовах Степу України на чорноземах типових малогумусних. У результаті проведених нами досліджень встановлено, щзо в умовах зони Степу Украйни на чорноземах типових малогумусних формування високих урожаїв соняшника на рівні $2,7 \mathrm{~m} / 2$ a забезпечують гібриди PR64F50, PR64A15 за рекомендованого строку сівби (за прогрівання трунту на глибині $10 \mathrm{~cm}$ на $10-12{ }^{\circ} \mathrm{C}$ ) та ширини міжсядь $35 \mathrm{~cm}$.

Ключові слова: соняшник, строки сівби, способи сівби, гібриди урожайність, продуктивHicmb.

Постановка проблеми. В агропромисловому виробництві України провідне місце серед технічних культур посідає соняшник - основна олійна культура. На соняшникову олію припадає 98 \% від загального виробництва олії в Україні. Соняшник - одна 3 найбільш прибуткових та високоліквідних культур. А враховуючи те, що виробництво соняшнику на сільськогосподарських підприємствах не завжди супроводжується інтенсифікацією, а в основному ведеться шляхом екстенсивних технологій, то посівні площі під ним останніми рокам різко збільшились, що зумовило знищення агрономічно-обгрунтованої структури посівних площ у деяких регіонах України. Нині рівень використання біологічного потенціалу соняшнику $\epsilon$ найменшим серед олійних культур і навіть не досягає 50 \%. Ефективність функціонування олійножирового підкомплексу України значною мірою залежить від стабільного та ефективного виробництва соняшнику на сільськогосподарських підприємствах.

3 появою у виробництві нових гібридів соняшнику особливого практичного значення набуває встановлення для них оптимальних параметрів основних агротехнічних прийомів вирощування, зокрема строків та способів сівби, що дасть змогу більш повно реалізувати їх біологічний потенціал.

Аналіз останніх досліджень і публікацій. Літературні дані засвідчують, що найбільш ефективно використовують родючість грунту, i саме тому дають найбільший урожай насіння і вихід олії, посіви соняшника з густотою, яка забезпечує завчасно початок конкуренції, в результаті чого до цвітіння рослини встигають поглинути запаси поживних речовин із грунту i, в деякій мірі, пригнічують ріст вегетативних органів до початку росту насіння. Строки сівби та ширина міжрядь за вирощування соняшника не $є$ чітко визначеним показником, а потребує уточнення залежно від гібриду, грунтово-кліматичних особливостей зони вирощування, добрив, способу сівби та інших елементів технології $[3,4]$.

Разом 3 тим, попередніми дослідженнями встановлено, що врожайність соняшника різних сортотипів (скс, pc, сp, сc) підвищується у випадку, коли площа живлення рослини становить

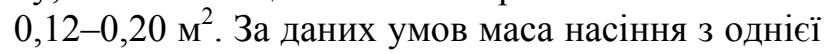
рослини може бути у 2,5-3 рази меншою по відношенню до максимально можливої $[1,2]$.

Надмірне загущення посівів призводить до зниження врожайності соняшника у зв'язку 3 посиленням конкуренції між рослинами. У посівах 3 високою густотою стояння рослин спостерігається більша витрата запасів вологи до настання генеративного періоду. За рівномірного розміщення рослин на площі їх взаємне пригнічення починається пізніше. Встановлено також, що в густіших посівах взаємне пригнічення рослин починає негативно впливати на формування вегетативної маси агроценозу, починаючи з фази бутонізації [5]

Серед агротехнічних заходів, спрямованих на підвищення врожайності соняшнику, важливе місце належить вибору гібриду, оптимальних способів сівби i ширини міжрядь, 3 якими пов'язана площа живлення рослин та їі конфігурація.

За традиційної технології вирощування $з$ густотою рослин 45-60 тис. шт./га площа живлення однієї рослини соняшника становить 0,17-0,22 м², а іï форма нагадує видовжений прямокутник зі сторонами 70 × 24-30 см. За такою схемою розміщення, рослини толерантних до загущення гібридів не реалізують свій потенціал продуктивності.

Дослідження останніх років, проведені в цен- 


\section{СІЛЬСЬКЕ ГОСПОДАРСТВО. РОСЛИННИЦТВО}

тральному, східному і південному Степу України, доводять ефективність вирощування гібридів соняшнику зі звуженими міжряддями $(45,30,15$ см) за збільшеної густоти рослин. Однак межі оптимального загущення визначаються конкретними природно-кліматичними умовами, біологічними особливостями гібридів тощо. Недостатньо вивченим залишається вплив способу сівби на якісні показники урожаю та його структуру, споживання елементів мінерального живлення та вологи. Це спонукає до розширення досліджень і вивчення реакції вітчизняних та іноземних гібридів соняшника на ширину міжрядь в умовах Степу України.

Метою наших досліджень було вивчення впливу строків сівби та ширини міжрядь нових гібридів соняшнику на формування продуктивності культури в умовах Степу на чорноземах типових малогумусних.

Матеріали і методи досліджень. Технологія вирощування культури є загальноприйнятою для зони Степу України за винятком досліджуваних елементів. Предметом дослідження були посіви соняшнику гібридів Форвард, Ясон, PR64F50, PR64A15, PR64A89.

Дослідження проводили відповідно до загальноприйнятих методик. Польові досліди закладали за методом розщеплених ділянок. Дослід трифакторний. Фактор $A$ - гібриди: Форвард, Ясон, PR64F50, PR64A15, PR64A89. Фактор Bширина міжрядь: 35, 45, 70 см. Фактор $C$ строки сівби: 1) ранній - за досягнення температури грунту на глибині $10 \mathrm{~cm} \mathrm{6-8}{ }^{\circ} \mathrm{C}$; 2) рекомендований - за $10-12{ }^{\circ} \mathrm{C} ; 3$ ) пізній - за $14-16{ }^{\circ} \mathrm{C}$.
Результати проведених досліджень. Попередні дослідження засвідчують, що зміною строків сівби можна створити кращі умови для росту та розвитку рослин соняшнику, таким чином уникнувши впливу несприятливих умов саме в критичні фази їхнього розвитку по відношенню до вологи.

Результати проведених нами досліджень свідчать, що кожен із досліджуваних гібридів мав свою специфічну реакцію на дію експериментальних чинників. Так, найвищі показники урожайності у гібридів PR64F50, PR64A15 та Ясон були отримані за висівання їх у рекомендовані строки (за прогрівання грунту на глибині $10 \mathrm{~cm}$ на $10-12{ }^{\circ} \mathrm{C}$ ) та за сівби 3 шириною міжрядь 35 см. Ці показники становили: у гібриду PR64F50 2,58 т/га, у PR64A15 - 2,7 т/га, у гібриду Ясон 2,38 т/га (див. табл.). Варто також зазначити, що у вищезгаданих гібридів по мірі збільшення ширини міжрядь спостерігалась чітка тенденція до зниження урожайності культури.

Реакція гібридів PR64A89 та Форвард на досліджувані фактори була абсолютно іншою порівняно із залежностями вищенаведених гібридів. Так, за сівби цих гібридів посіви культури максимальну урожайність формували за раннього строку сівби (за досягнення температури грунту на глибині $10 \mathrm{~cm} 6-8{ }^{\circ} \mathrm{C}$ ) та ширини міжрядь 45 см. Вона становила у гібриду PR64A89 2,57 т/га та Форвард - 2,43 т/га. Варто зазначити, що чіткої залежності між показниками урожайності, як у гібридів PR64F50, PR64A15 та Ясон відмічено не було.

Урожайність залежнно від строків та способів сівби, m/2а (середнє за 2014-2016 рр.)

\begin{tabular}{|c|c|c|c|c|}
\hline \multirow{2}{*}{ Гібрид } & \multirow{2}{*}{ Ширина міжрядь } & \multicolumn{3}{|c|}{ Строки сівби } \\
\hline & & Ранній & Рекомендований & Пізній \\
\hline \multirow{3}{*}{ PR64F50 } & 35 & 2,53 & 2,68 & 2,26 \\
\hline & 45 & 2,23 & 2,35 & 2,14 \\
\hline & 70 & 1,86 & 2,06 & 1,89 \\
\hline \multirow{3}{*}{ PR64A15 } & 35 & 2,49 & 2,70 & 2,13 \\
\hline & 45 & 2,48 & 2,45 & 2,25 \\
\hline & 70 & 2,20 & 2,27 & 2,25 \\
\hline \multirow{3}{*}{ PR64A89 } & 35 & 2,28 & 2,45 & 2,21 \\
\hline & 45 & 2,57 & 2,31 & 2,16 \\
\hline & 70 & 2,40 & 2,28 & 2,14 \\
\hline \multirow{3}{*}{ Форвард } & 35 & 1,94 & 2,07 & 1,72 \\
\hline & 45 & 2,43 & 1,98 & 1,86 \\
\hline & 70 & 1,86 & 2,04 & 1,94 \\
\hline \multirow{3}{*}{ Ясон } & 35 & 2,03 & 2,38 & 2,16 \\
\hline & 45 & 2,19 & 2,36 & 2,18 \\
\hline & 70 & 1,19 & 23,1 & 2,10 \\
\hline
\end{tabular}


Висновок. Дослідження, проведені в умовах зони Степу України на чорноземах типових малогумусних показали, що формування високих урожаїв соняшника на рівні 2,7 т/га забезпечу-

\section{БІБЛІОГРАФІЯ}

1. Васильев Д. С. Способы, сроки сева и густота стояния / Д. С. Васильев, В. И. Марин, Л. И. Токарева // Технические культуры. - 1990. №2. - С. 8-9.

2. Дребот В.А. Продуктивность гибридов подсолнечника и их родительских форм в зависимости от пространственного размещения растений / В.А.Дребот // Интенсификация производства технических и кормовых культур. 1990. - C. 4-10.

3. Коритник В. М. Визначення оптимальної густоти стояння рослин в залежності від групи стиглості гібридів, строків сівби, ширини міжрядь та частки вкладу цих факторів у формування врожаю соняшнику в Північно-східному ре- ються за вирощування гібридів PR64F50, PR64A15 за рекомендованого строку сівби (за прогрівання грунту на глибині 10 см на $10-12{ }^{\circ} \mathrm{C}$ ) та ширини міжрядь 35 см.

гіоні України / В. М. Коритник, М.П.Бондаренко, А. Г. Письменний // Бюлетень Інституту зернового господарства. - Дніпропетровськ, 2001. - №17. - С. 62-64.

4. Мінковський А. С. Реакція гібридів соняшнику на ширину міжрядь, густоту посівів та конкурентноздатність відносно бур'янів / А. Є. Мінковський // Бюлетень Інституту зернового господарства. - Дніпропетровськ, 2000. №14. - C. 27-29.

5. Олексюк О. М. Вплив способів сівби і густоти стояння рослин на урожайність гібридів соняшника в північній частині Степу України : автореф. дис. на здобуття наук. ступеня к. с.-г. н. / О. М. Олексюк. -Дніпропетровськ, 2000. - 16 с. 